\title{
Immunochemical and clinical effects of immunosuppressive treatment in monoclonal IgM neuropathy
}

\author{
J H Ernerudh, M Vrethem, O Andersen, C Lindberg, G Berlin
}

Faculty of Health Science, University Hospital, Linköping, Sweden

Department of

Neurology

J H Ernerudh

M Vrethem

Department of Transfusion, Medicine and Clinical

Immunology

G Berlin

Department of

Neurology,

Sahlgrenska Hospital,

Gothenburg

$\mathrm{O}$ Andersen

C Lindberg

Correspondence to:

Dr Jan $\mathrm{H}$ Ernerudh

Department of Neurology,

University Hospital, S-581

85 Linköping, Sweden

Received 10 July 1991

and in final revised form

27 January 1992.

Accepted 6 February 1992

\begin{abstract}
A pathogenic role of the $M$ protein in monoclonal IgM neuropathy has been suggested. This is based among other things on a close relation between immunosuppressive treatment, lowered concentration of $M$ protein, and clinical effect. We studied five patients with monoclonal IgM and antibodies to peripheral nerve myelin. The immunosuppressive treatment was beneficial in three of the patients. In three patients there was a relationship between antibody concentration and clinical effect (in one there was no change in antibody concentrations and correspondingly no change in clinical status, and in two patients clinical improvement corresponded to decreased antibody concentrations). In two patients, however, there was no clear correlation, since one patient improved despite increasing antibody concentrations and one patient did not improve despite a lowered antibody concentration. It is therefore possible that other mechanisms may contribute to the effect of treatment.
\end{abstract}

\section{(F Neurol Neurosurg Psychiatry 1992;55:930-934)}

IgM monoclonal gammopathy may be associated with a demyelinating peripheral neuropathy. ${ }^{12}$ Antibodies occur in some patients, directed against peripheral nerve myelin $(\mathrm{PNM})^{3}$ or its subcomponents, especially myelin associated glycoprotein (MAG). ${ }^{12}$ These antibodies are probably of primary pathogenic relevance; this is supported by histological studies showing IgM deposits in nerves in biopsy specimens, ${ }^{4-6}$ and by experimental studies showing that the neuropathy can be passively transferred by intraneural injections of monoclonal (M) proteins. ${ }^{7-9}$ Also, the beneficial effect of lowering the serum concentration of the $M$ protein by immunosuppressive treatment or by plasma exchange indicates a pathogenic role of the $M$ protein, although the results of immunosuppressive treatment of IgM monoclonal neuropathy are conflicting. ${ }^{610-24}$ Another possibility is that the antibodies to PNM represent a secondary phenomenon with uncertain pathogenic importance. This is supported by the finding that normal controls may have antibodies against certain glycolipids ${ }^{25}$ or PNM, ${ }^{326}$ even in the absence of clinical or subclinical neuropathy. ${ }^{27}$ In addition, many patients with IgM monoclonal neuropathy do not have antibodies to myelin; this underlines that other mechanisms may operate in the development of the neuropathy.

To elucidate the clinical outcome in relation to antibodies to PNM and M protein, as well as in relation to treatment, we report a longitudinal study of five patients with monoclonal IgM and neuropathy treated with immunosuppressive agents.

\section{Patients and methods}

Table 1 shows the characteristics of five patients with monoclonal IgM, peripheral neuropathy, and antibodies to PNM. All had a chronic progressive symmetrical sensorymotor polyneuropathy. All patients had IgM kappa paraproteins and were diagnosed as having monoclonal gammopathy of unknown significance (MGUS) on the basis of bone

Table 1 Clinical and laboratory data on patients with monoclonal IgM neuropathy

\begin{tabular}{|c|c|c|c|c|c|c|c|c|c|c|}
\hline \multirow[b]{2}{*}{$\begin{array}{l}\text { Patient } \\
\text { no }\end{array}$} & \multirow[b]{2}{*}{$\begin{array}{l}\text { Sexl } \\
\text { age }\end{array}$} & \multirow{2}{*}{$\begin{array}{l}\text { Duration } \\
\text { of } \\
\text { disease } \\
\text { (years) }\end{array}$} & \multirow{2}{*}{$\begin{array}{l}\text { Total } \\
\text { serum } \\
\operatorname{IgM}(g / l)\end{array}$} & \multirow{2}{*}{$\begin{array}{l}\text { ELISA for } \\
\text { anti-PNM } \\
\text { antibody }\end{array}$} & \multicolumn{2}{|c|}{ Nerve conduction velocity $(\mathrm{m} / \mathrm{s})$} & \multirow[b]{2}{*}{$\begin{array}{l}\text { Disability status/t } \\
\text { Ataxia score } \neq\end{array}$} & \multirow[b]{2}{*}{$\begin{array}{l}\text { Type of } \\
\text { treatment }\end{array}$} & \multirow[b]{2}{*}{$\begin{array}{l}\text { Effect of } \\
\text { treatment }\end{array}$} & \multirow{2}{*}{$\begin{array}{l}\text { Level of anti-PNM } \\
\text { antibodies during } \\
\text { treatment§ }\end{array}$} \\
\hline & & & & & $\begin{array}{l}\text { Motor nerves } \\
\text { Median/Peroneal }\end{array}$ & $\begin{array}{l}\text { Sensory nerves } \\
\text { Median/Sural }\end{array}$ & & & & \\
\hline $\begin{array}{l}1 \\
2 \\
3 \\
4 \\
5\end{array}$ & $\begin{array}{l}M / 44 \\
M / 75 \\
F / 60 \\
F / 65 \\
M / 69\end{array}$ & $\begin{array}{r}4 \\
4 \\
1 \\
3 \\
10\end{array}$ & $\begin{array}{r}6 \cdot 8 \\
8 \cdot 6 \\
5 \cdot 1 \\
10 \cdot 0 \\
3 \cdot 0\end{array}$ & $\begin{array}{l}+++ \\
+ \\
++ \\
++ \\
+\end{array}$ & $\begin{array}{l}21 / 0 \\
45 / 7 \\
43 / 21 \\
30 / 12 \\
10 / 0\end{array}$ & $\begin{array}{l}12 / 0 \\
45 / 0 \\
51 / 30 \\
0 / 0 \\
0 / 0\end{array}$ & $\begin{array}{l}3 \cdot 5 / 3 \\
2 \cdot 5 / 2 \\
3 / 3 \\
4 / 3 \\
4 / 5\end{array}$ & $\begin{array}{l}\text { PE, Ch, P } \\
\text { P } \\
\text { P } \\
\text { Ch, M } \\
\text { P, Ch }\end{array}$ & $\begin{array}{l}+ \\
0 \\
++ \\
0 \\
++\end{array}$ & $\begin{array}{l}\downarrow \text { Decreased } \\
\downarrow \text { Decreased } \\
\uparrow \text { Increased } \\
\text {-Unchanged } \\
\downarrow \text { Decreased }\end{array}$ \\
\hline
\end{tabular}

$\mathrm{PE}=$ plasma exchange, $\mathrm{Ch}=$ chlorambucil, $\mathrm{P}=$ prednisolone, $\mathrm{M}=$ melphalan

$\star$ Anti-PNM $=$ anti-peripheral nerve myelin. Grading of ELISA $+++=75-125,++=50-75,+=30-50 \%$ of positive control.

$\star$ Anti-PNM $=$ anti-peripheral nerve myelin. Grading of ELISA; $+++=75-125,++=50-75,+=30-50 \%$ of positive control.
+ Modified from Prineas
${ }^{2} ; 0=$ normal; $1=$ signs but no symptoms; $2=$ mild motor and/or sensory symptoms without or with $(=2 \cdot 5)$ mild functional

Modified from Prineas $; 0=$ normal; $1=$ signs but no symptoms; $2=$ mild motor and/or sensory symptoms without or with $(=2.5)$ mild functional
impairment; $3=$ moderately disabled including sensory ataxia; $4=$ required assistance in eating, dressing, or used a walking aid (3.5 $=4$ but only to a minor impairment; $3=$ moderately

extent), $5=$ not ambulant.
$\neq 0=$ normal (stand on one foot with eyes closed); $1=$ stand/walk normally with eyes closed; $2=$ stand/walk with minor swaying with eyes closed but normally $\ddagger 0=$ normal (stand on one foot with eyes closed); $1=$ stand/walk normally with eyes closed; $2=$ stand/walk with minor swaying with eyes closed but nor
with eyes open; $3=$ stand/walk with some swaying with eyes open; $4=$ stand/walk on large base with eyes open; $5=$ standing/walking impossible without support. ${ }^{2}$

$\| 0=$ No effect, $+=$ stabilisation or slight improvement of neuropathy, $++=$ clear objective and subjective improvement of neuropathy

$\S \geqslant 40 \%$ Change on two occasions in comparison to the initial value.

Only one post-treatment sample was available. 
marrow findings, skeletal survey, and blood tests. Apart from the $\mathbf{M}$ protein there was no other known cause of polyneuropathy. Nerve biopsies showed predominant demyelination and Western blot analyses showed reactivity against MAG. $^{3}$

Five patients with IgM monoclonal demyeli-
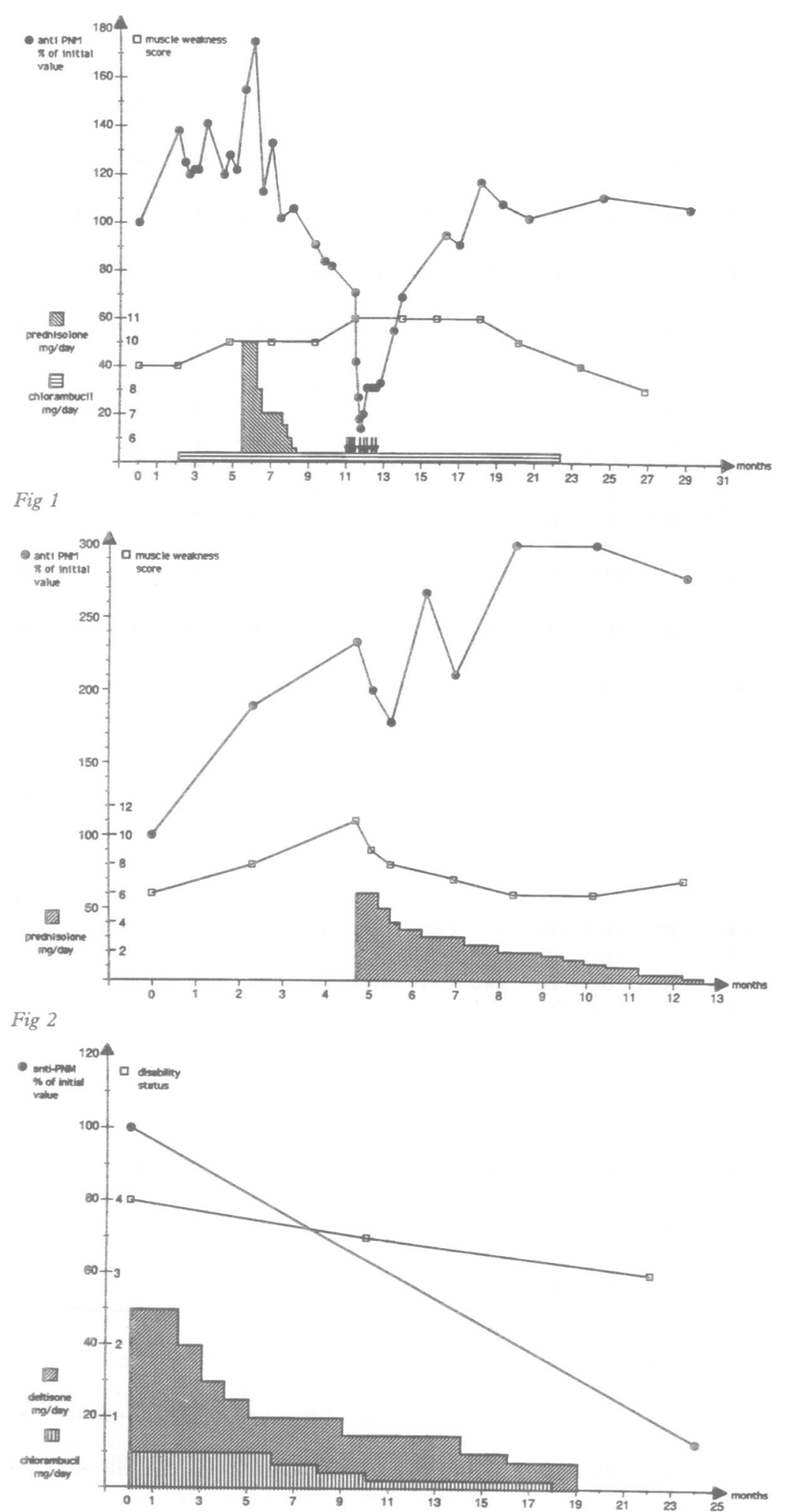

Fig 3

Concentrations of peripheral nerve myelin (PNM) antibodies (O) in relation to treatment and clinical outcome in patients No 1 (fig 1), No 3 (fig 2), and No 5 (fig 3). The left part of the $Y$ axis shows the concentration of antibody to PNM expressed as a percentge of initial values, as well as immunosuppressive treatment (mg/day). The right part of the Y-axis the score of clinical status that best describes any change in status. $\downarrow$ in fig 1 denotes plasma exchange. nating neuropathy and antibodies to PNM were monitored longitudinally during immunosuppressive treatment.

The IgM concentration in serum was determined by radial immune diffusion technique. Antibodies to PNM were detected by enzyme linked immunosorbent assay (ELISA) slightly modified from a previous description. ${ }^{18}$ Briefly, bovine PNM was isolated from the lumbosacral plexus. ${ }^{29}$ Microtitre plates were coated with $0 \cdot 1 \mathrm{ml}$ per well of bovine PNM $(80 \mu \mathrm{g} / \mathrm{ml})$ in 0.05 sodium carbonate buffer, $\mathrm{pH} 9 \cdot 6$. A serum IgM concentration of $15 \mathrm{mg} /$ 1 was chosen because it gave optimal discrimination between positive and negative controls, and placed the antibody concentration at a linear part of the curve. Microtitre plates were incubated for one hour at room temperature with $0.1 \mathrm{ml}$ of the serum samples, all adjusted to $15 \mathrm{mg} / \mathrm{l}$ of $\mathrm{IgM}$, and thereafter washed. Then alkaline phosphatase conjugated antihuman IgM antiserum (Sigma, St Louis, USA), diluted to 1/2500, was added for one hour. After washing, enzyme reaction was initiated. Absorbance photometry was done when the optical density of the positive control, included on each plate, reached $1 \cdot 2$. Negative controls did not exceed an optical density of $0 \cdot 2$. For longitudinal studies all samples from one patient were included on the same microtitre plate. The results were corrected for the dilution (by multiplication with the coefficient of dilution) to get a measure of the total amount of antibodies in serum. To facilitate comparison, longitudinal results were expressed as a percentage of the initial value. To test for the stability of concentrations of antibody to PNM, six consecutive samples taken at intervals of a week from patient (No 2) not being given treatment were reanalysed on one plate. The coefficient of variation was $7 \%$.

For clinical estimation (table 1) a disability status (scale) modified from Prineas and an ataxia score according to Prineas were used. ${ }^{28}$ The muscle weakness score from Osterman et $a .^{30}$ consisted of a scale ranging from normal power (0) to no active movement (4) used on six different muscle groups; a corresponding scale for cranial nerve involvement ranged from 0 to 3 . The muscle weakness score was calculated as the sum of the seven muscle groups tested. Thus, the range was from 0 (normal motor function) to 27 (total paralysis in all muscles examined).

\section{Results}

Table 1 summarises clinical outcome and effect of immuno-suppressive treatment on antibodies to PNM. Data on three patients (shown in figures as examples) show improvement related to lowered antibody concentration (figs 1 and 3) and despite increased antibody concentration (fig 2). The most appropriate scale to show change in clinical status was chosen (muscle weakness score in figs 1 and 3, disability status in the patient with predominating ataxia (fig 3)).

Patient No 1 had a polyneuropathy initially 
affecting lower extremities. Previous treatment with plasma exchange, without any immunosuppressive drugs, resulted in improved motor and sensory function in the feet. ${ }^{18}$ After eight months, however, a slow deterioration again started, now also involving the hands, and therefore a new series of plasma exchange was performed. After six treatments during two weeks, the interval between treatments was gradually increased to one week, two weeks, and finally one month. IgM and antibodies to PNM decreased during the intensive treatment period, as in the previous study, ${ }^{18}$ and remained at a low level during the period with weekly plasma exchange but increased when the interval was two weeks or longer (data not shown). The patient did not improve, and chlorambucil $6 \mathrm{mg} /$ day was started (fig 1). Prednisolone was added for a time, but clinical deterioration continued; therefore a new series of plasma exchange (six treatments during two weeks, and then once weekly for five weeks) was performed during continuous chlorambucil treatment. The patient's clinical status then stabilised, and after six months a clear improvement was noted (fig 1), especially in the motor function of his hands. Chlorambucil was given for a total of 21 months. The patient's clinical status remained stable for two years; when it worsened chlorambucil was started again.

Patient No 2, had a low concentration of IgM $M$ protein which increased slowly. After four years of slow progression of the neuropathy, prednisolone treatment was tried (starting dose $50 \mathrm{mg} /$ day, tapering off during eight months). There was no objective or subjective improvement during or after the treatment period. Disability status and sensory status, as well as muscle weakness score, remained unchanged.

Patient No 3 showed a clear and prompt improvement after four weeks of prednisolone treatment (starting dose $60 \mathrm{mg}$, tapering off during eight months). The concentration of antibodies to PNM increased despite the clinical improvement (fig 2).

Patient No 4 had been treated with melphalan and prednisolone, inducing a temporary stop of the progression. When she was included in the present study her symptoms had worsened; a new treatment programme with melphalan (three cycles of $15 \mathrm{mg}$ daily for four days) and later chlorambucil (10 mg daily for three weeks) was initiated. No clinical effect was noted and the concentration of antibodies to PNM did not change significantly.

Patient No 5 showed a clear improvement after two months' treatment with prednisolone (50 mg per day, tapering off during 18 months) and chlorambucil (10 mg/day for six months, tapering off during the next 12 months). The concentration of antibodies to PNM decreased during treatment (fig 3).

\section{Discussion}

Immunosuppressive treatment was beneficial in three of our five patients with monoclonal IgM and polyneuropathy. All five patients belonged to the entity of polyneuropathy of probable immune mediated aetiology, on the basis of morphological studies showing demyelinating neuropathy and monoclonal IgM deposits, and also occurrence of antibodies reacting against PNM. The antibodies to PNM in our patients were also specific for myelin associated glycoprotein although we used the more accessible PNM for this longitudinal study.

In three patients we found a clear correlation between clinical effect during treatment and concentration of antibodies to PNM: in two patients clinical improvement corresponded to decreased antibody concentrations and in one patient clinicial status as well as antibody concentration was unchanged. Our results thus corroborate a previous report of clinical improvement in two patients closely related to reduced $M$ protein, whereas in 3 patients who did not respond to treatment the concentration of $M$ protein were unchanged. ${ }^{20}$ In two of our patients, however, there was no clear correlation between clinical effect and concentration of antibodies, since one patient improved despite unchanged or increased antibodies to PNM and one patient did not improve despite lowered antibody concentrations. The difference between the studies clearly could have been caused by the heterogeneity and small sizes of the patient groups. Our results, however, indicate that the recorded effect on concentrations of $M$ protein or antibodies to PNM is not crucial for the clinical outcome in individual patients. In addition, it is known that patients without antibodies to myelin also may respond to immunosuppressive treatment. ${ }^{1921}$ Therefore, treatment effects other than the lowered $M$ protein or antibody concentrations may be involved. Studies on cellular mechanisms may be of interest here.

A correlation between lowered $M$ protein or antibody concentrations and clinical improvement should not necessarily be interpreted as a causal relation. It may simply be that high doses of immunosuppressive drugs are clinically more effective and also more likely to decrease the $\mathbf{M}$ protein or antibody concentrations.

There was a delay of two to six months between the treatment period and clinical improvement in two patients with lowered antibodies to PNM. Considering that there is established demyelination in the peripheral nerves, it is reasonable to expect a delay until improvement is noted, and this should be taken into account when deciding the length of a treatment period.

Previous experience in treating monoclonal IgM neuropathies is summarised in table 2 . Although it is difficult to compare studies, on the whole immunosuppressive treatment may stabilise or slightly improve the disease (12 patients), clearly improve the symptoms (23 patients), or have no beneficial effect ( 9 patients). The studies are small and open, but as spontaneous improvement does not (to our knowledge) occur, immunosuppressive treatment may be beneficial in many patients, but it is not possible to predict which patients could 
Table 2 Comparison between studies of clinical effect of immunosuppressive treatment of monoclonal IgM neuropathy

\begin{tabular}{|c|c|c|c|c|c|c|c|c|c|c|}
\hline \multirow[b]{2}{*}{ Author } & \multirow{2}{*}{$\begin{array}{l}\text { No of } \\
\text { patients }\end{array}$} & \multirow[b]{2}{*}{ Type of disease } & \multicolumn{3}{|c|}{$\begin{array}{l}\text { Anti-myelin } \\
\text { antibodies }\end{array}$} & \multirow[b]{2}{*}{ Treatment } & \multicolumn{3}{|c|}{$\begin{array}{l}\text { Effect of } \\
\text { treatmentt }\end{array}$} & \multirow{2}{*}{$\begin{array}{l}\text { Adverse } \\
\text { effects }\end{array}$} \\
\hline & & & + & - & Not done & & 0 & + & ++ & \\
\hline $\begin{array}{l}\text { Latov et al }(1980)^{10} \\
\text { Dalakas and Engel }(1981)^{11}\end{array}$ & $\begin{array}{l}1 \\
4\end{array}$ & $\begin{array}{l}\text { MGUS } \\
\text { MGUS }\end{array}$ & $1 \ddagger$ & $\overline{1}$ & $\overline{2}$ & $\begin{array}{l}P E+P+C h \\
P(n=1) \\
P+C h(n=1) \\
\text { None }(n=2)\end{array}$ & $\overline{1}$ & $\frac{1}{1}$ & $\begin{array}{l}- \\
- \\
-\end{array}$ & $\begin{array}{l}\text { None } \\
\text { None }\end{array}$ \\
\hline Dalakas et al $(1983)^{12}$ & 1 & Mb Waldenström & 1 & - & - & $\mathrm{PE}+\mathrm{P}+\mathrm{Ch}$ & - & - & 1 & $\begin{array}{l}\text { PE discontinued because } \\
\text { of tachyarrhythmia }\end{array}$ \\
\hline Stefansson et al $(1983)^{6}$ & 1 & MGUS & 1 & - & - & $\begin{array}{l}\text { PE + other } \\
\text { immunosuppressive drugs }\end{array}$ & 1 & - & - & Not mentioned \\
\hline Melmed et al $(1983)^{13}$ & 3 & MGUS & 3 & - & - & $\begin{array}{l}\mathbf{P E}+\mathbf{P}+\mathrm{Ch}(\mathbf{n}=1) \\
\mathbf{P E}+\mathbf{P}+\mathbf{A z}(\mathbf{n}=1) \\
\mathbf{P}+\mathrm{Ch}(\mathbf{n}=\mathbf{1})\end{array}$ & $\begin{array}{l}- \\
- \\
-\end{array}$ & $\begin{array}{l}1 \\
1\end{array}$ & $\begin{array}{l}- \\
-\end{array}$ & $\begin{array}{l}\text { Bonemarrow depression } \\
\text { in one }\end{array}$ \\
\hline $\begin{array}{l}\text { Meier et al }(1984)^{14} \\
\text { Sherman et al }(1984)^{15}\end{array}$ & $\begin{array}{l}1 \\
6\end{array}$ & $\begin{array}{l}\text { Mb Waldenström } \\
\text { MGUS }(n=5) \\
\text { Lymphoma }(n=1)\end{array}$ & 1 & - & $\overline{6}$ & $\begin{array}{l}\mathrm{PE}+\mathrm{P}+\mathrm{Ch} \\
\mathrm{PE}(\mathrm{n}=3) \\
\mathrm{PE}+\mathrm{Ch}(\mathrm{n}=3)\end{array}$ & $\frac{-}{1}$ & $\begin{array}{l}- \\
1 \\
2\end{array}$ & $\begin{array}{l}1 \\
1 \\
1\end{array}$ & $\begin{array}{l}\text { None } \\
\text { None }\end{array}$ \\
\hline $\begin{array}{l}\text { Julien et al }(1984)^{16} \\
\text { Kiprov and Miller }(1985)^{17} \\
\text { Ernerudh et al }(1986)^{18}\end{array}$ & $\begin{array}{l}1 \\
1 \\
3\end{array}$ & $\begin{array}{l}\text { MGUS } \\
\text { MGUS } \\
\text { MGUS }\end{array}$ & $\frac{1}{3}$ & $\begin{array}{l}- \\
- \\
-\end{array}$ & $\overline{1}$ & $\begin{array}{l}\mathrm{P} \\
\mathrm{PE}\end{array}$ & $\overline{1}$ & $\begin{array}{l}- \\
1\end{array}$ & $\begin{array}{l}1 \\
1 \\
1\end{array}$ & $\begin{array}{l}\text { None } \\
\text { None } \\
\text { None }\end{array}$ \\
\hline Smith et al $(1987)^{19}$ & 8 & $\begin{array}{l}\text { MGUS }(n=6) \text { Lym- } \\
\text { phoma }(n=2)\end{array}$ & 4 & 4 & - & $\begin{array}{l}\mathrm{PE}+(\mathrm{Cy}, \mathrm{Ch}, \mathrm{M} \text { or } \mathrm{Ad}) \\
(\mathrm{n}=5) \\
\mathrm{PE}(\mathrm{n}=2) \\
\mathrm{Cy}+(\mathrm{Ch}, \mathrm{Ad} \text { or } \mathrm{M})(\mathrm{n}=1)\end{array}$ & $\begin{array}{l}1 \\
1 \\
-\end{array}$ & $\begin{array}{l}1 \\
1 \\
1\end{array}$ & $\begin{array}{l}3 \\
- \\
-\end{array}$ & Not mentioned \\
\hline Nobile-Orazio et al $(1988)^{20}$ & 5 & $\begin{array}{l}\text { MGUS (n= 3) } \\
\text { Mb Waldenström (2) }\end{array}$ & 5 & - & - & $\begin{array}{l}C h(n=2) \\
C h+C y(n=1) \\
C h+C y+P(n=1) \\
C h+P(n=1)\end{array}$ & $\begin{array}{l}1 \\
1 \\
1 \\
-\end{array}$ & $\begin{array}{l}- \\
- \\
- \\
-\end{array}$ & $\begin{array}{l}- \\
- \\
- \\
1\end{array}$ & Infection in one patient \\
\hline Kelly et al (1988) $)^{21}$ & 10 & $\begin{array}{l}\text { MGUS }(n=7) \\
\text { Lymphoma }(n=1) \\
\text { CIDP }(n=1) \\
\text { Carcinoma }(n=1)\end{array}$ & 5 & 5 & - & $\begin{array}{l}\mathrm{PE}+\mathrm{P}+(\mathrm{Ch}, \mathrm{Az} \text { or } \mathrm{Cy}) \\
(\mathbf{n}=7) \text { No }(\mathbf{n}=3)\end{array}$ & - & - & 7 & $\begin{array}{l}\text { One patient died in } \\
\text { sepsis and one had a } \\
\text { compression fracture }\end{array}$ \\
\hline $\begin{array}{l}\text { Haas and Tatum }(1988)^{22} \\
\text { Donofrio and Kelly }(1989)^{23}\end{array}$ & $\begin{array}{l}1 \\
1\end{array}$ & $\begin{array}{l}\text { MGUS } \\
\text { MGUS }\end{array}$ & 1 & $\overline{1}$ & - & $\begin{array}{l}\mathrm{PE} \\
\mathbf{P E}\end{array}+\mathbf{P}+\mathbf{A z}+\mathbf{M}$ & $\overline{-}$ & - & $\begin{array}{l}1 \\
1\end{array}$ & $\begin{array}{l}\text { None } \\
\text { Pancytopenia when } \\
\text { treated with Az }\end{array}$ \\
\hline Cook et al $(1990)^{24}$ & 2 & MGUS & $2 \|$ & - & - & Intravenous immunglobulin & - & - & 2 & Headache \\
\hline
\end{tabular}

MGUS = Monoclonal gammopathy of unknown significance, CIDP = Chronic inflammatory demyelinating polyradiculoneuropathy.

$\mathrm{PE}=$ Plasma exchange, $\mathbf{P}=$ prednisolone, $\mathrm{Ch}=$ chlorambucil, $\mathrm{Cy}=$ cyclophosphamide, $\mathbf{M}=$ melphalan, $\mathrm{Ad}=\mathrm{adriamycin}, \mathrm{Az}=$ azathioprine. $\star$ Anti-nerve antibody reactivity against myelin-associated glycoprotein (MAG) or myelin preparations, $+=$ positive, $-=$ negative.

to = no effect, $+=$ stabilisation or slight improvement of the neuropathy, $++=$ clear objective and subjective improvement of neuropathy.

fImmunofluorescence studies of nerve biopsy deposits.

|| One patient had antibodies to gangliosides and one to myelin associated glycoprotein.

benefit. Our observations support an early start of treatment, before the nerves are irreversibly damaged. One patient with a short history (less than one year) responded well to prednisolone treatment and another, with a long history (four years) did not respond to the same treatment. Furthermore, in the patients treated at different times the later treatments were not as successful as the initial treatments.

Plasma exchange lowers the concentration of $\mathrm{M}$ proteins, ${ }^{15} 18$ but long term treatment with short intervals is needed to keep the $M$ protein at a low level ${ }^{22}$; this accords with the experiences from one of our patients.

In conclusion, the results of this open study suggest that immunosuppressive treatment is beneficial in some patients with monoclonal IgM neuropathy. We found a correlation between lowered antibodies to PNM and clinical improvement in three of our patients. In two patients, however, there was no such correlation, and it is therefore possible that at least in some patients other mechanisms may contribute to the effect of treatment. The delay from the start of treatment to the clinical improvement indicates that the treatment should be maintained, or given intermittently, for at least six months.

We wish to thank Mrs Christina Ekerfeldt for skillful technical assistance. The work was supported by grants from Östergötlands Läns Landsting, the Swedish Association of Neurologically Disabled, and the Swedish Society of Medicine.
1 Kelly JJ Jr. Peripheral neuropathies associated with monoclonal proteins: a clinical review. Muscle Nerve 1985;8:138-50.

2 Steck AJ, Murray N, Dellagi K, Brouet J-C, Seligmann M. Peripheral neuropathy associated with monoclonal IgM autoantibody. Ann Neurol 1987;22:764-7.

3 Cruz M, Ernerudh J, Olsson T, Höjeberg B, Link H. Occurrence and isotype of antibodies against peripheral nerve myelin in serum from patients with peripheral neuropathy and healthy controls. $\mathcal{f}$ Neurol Neurosurg Psychiatry 1988;51:820-5.

4 Smith IS, Kahn SN, Lacey BW, King HM, Eames EA, Whybrew DJ, et al. Chronic demyelinating neuropathy associated with benign IgM paraproteinemia. Brain 1983;106:169-95.

5 Meier C, Vandevelde M, Steck AJ, Zurbriggen A. Demyelinating polyneuropathy associated with monoclonal IgMparaproteinemia. $\mathcal{I}$ Neurol Sci 1983;63:353-67.

6 Stefanson K, Marton L, Antel JP, Wollmann RI, Roos RP, Chejfec G, et al. Neuropathy accompanying IgMk monoclonal gammopathy. Acta Neuropathol (Berl) 1983;59:255-61.

7 Hays AP, Latov N, Takatsu M, Sherman WH. Experimental demyelination induced by serum of patients with neuropathy and an anti-MAG IgM M-protein. Neurology 1987;37:242-56.

8 Willison HJ, Trapp BD, Bacher JD, Dalakas MC, Griffin JW, Quarles RH. Demyelination induced by intraneural injection of human antimyelin-associated glycoprotein antibodies. Muscle Nerve 1988;11:1169-76.

9 Trojaborg W, Galassi G, Hays AP, Lovelace RE, Alkaitis M, Latov N. Electrophysiologic study of demyelination induced by serum of patients with IgM $M$ proteins and neuropathy. Neurology 1989;39:1581-6.

10 Latov N, Sherman WH, Nemni R, Galassi G, Shyong JS, Penn AS, et al. Plasma cell dyscrasia and peripheral Penn AS, et al. Plasma cell dyscrasia and peripheral neuropathy with a monoclonal antibody to peri

11 Dalakas MC, Engel WK. Polyneuropathy with monoclonal gammopathy: studies of 11 patients. Ann Neurol 1981;10:45-52.

12 Dalakas MC, Flaum MA, Rick M, Engel WK, Gralnich HR. Treatment of Waldenström's macroglobulinemia: role of paraproteinema and immunologic studies. Neurology 1983;33:1406-10.

13 Melmed C, Frail D, Duncan I, Braun P, Danoff D, Finlayson $M$, et al. Peripheral neuropathy with IgM kappa monoclonal immunoglobulin directed against myelinassociated glycoprotein. Neurology 1983;33:1397-405.

14 Meier C, Roberts K, Steck AJ, Hess C, Miloni E, Tschopp 
Reduction of endoneurial IgM-deposits after treatment with chlorambucil and plasmapheresis. Acta Neuropathol (Berl) 1984;64:297-307.

15 Sherman WH, Olarte MR, McKiernan G, Sweeny K, Latov N, Pays A. Plasma exchange treatment of peripheral neuropathy associated with plasma cell dyscrasia. $\mathcal{f}$ Neurol Neurosurg Psychiatry 1984;47:813-19.

16 Julien J, Vital C, Vallat JM, Lagueny A, Ferrer X, Leboutet MJ. Chronic demyelinating neuropathy with IgM-producing lymphocytes in peripheral nerve and delayed appearance of "benign" monoclonal gammopathy. Neurology 1984;34:1387-9.

17 Kiprov DD, Miller RG. Paraproteinemia associated with demyelinating polyneuropathy or myositis: treatment with plasmapharesis and immunosuppressive drugs. Artif Organs 1985;9:47-52.

18 Ernerudh J, Brodtkorb E, Olsson T, Vedeler CA, Nyland $H_{\text {, }}$ Berlin G. Peripheral neuropathy and monoclonal IgM Berlin G. Peripheral neuropathy and monoclonal IgM
with antibody activity against peripheral nerve myelin effect of plasma exchange. $\mathcal{F}$ Neuroimmunol 1986;11:171-8.

19 Smith T, Sherman $W$, Olarte MR, Lovelace RE. Peripheral neuropathy associated with plasma cell dyscrasia: a clinical and electrophysiological follow-up study. Acta Neurol Scand 1987;75:244-8.

20 Nobile-Orazio E, Baldini L, Barbieri S, Marmiroli $P$ Spagnol G, Francomano E, et al. Treatment of patients with neuropathy and anti-MAG IgM M-proteins. Ann Neurol 1988;24:93-7.

21 Kelly JJ, Adelman LS, Berkman E, Bhan I. Polyneuropathies associated with IgM monoclonal gammopathies. Arch Neurol 1988;45:1355-9.
22 Haas DC, Tatum AH. Plasmapheresis alleviates neuropathy accompanying IgM antimyelin associated glycoprotein paraproteinemia. Ann Neurol 1988;23:394-6.

23 Donofrio PD, Kelly JJ, Jr. AAEE case report 17: periphera neuropathy in monoclonal gammopathy of undetermined significance. Muscle Nerve 1989;12:1-8.

24 Cook D, Dalakas M, Galdi A, Biondi D, Porter H. Highdose intravenous immunoglobulin in the treatment of demyelinating neuropathy associated with monoclonal gammopathy. Neurology 1990;40:212-4.

25 McGinnis S, Kohriyama T, Yu RK et al. Antibodies to sulphated glucuronic acid containing glycosphingilipids sulphated glucuronic acid containing glycosphingilipids in neuropathy associated with anti-MAG antibodies and

26 Vedeler CA, Matre R, Nyland $H$. Class and Ig G subclass distribution of antibodies against peripheral nerve myelin in sera from patients with inflammatory demyelinating polyradiculoneuropathy. Acta Neurol Scand 1988;78:401-7.

27 Vrethem M, Skogh T, Holmgren H, Ernerudh J. Antibodies to peripheral nerve myelin may occur without clinical neuropathy in healthy persons. $f$ Neuroimmunol 1991;32:219-22.

28 Prineas J. Polyneuropathies of undetermined cause. Acto Neurol Scand 1970;46:(suppl 44):14-15.

29 Kadlubowski M, Hughes RA, Gregson NA. Experimental allergic neuritis in Lewis rat-characterization of the allergic neuritis in Lewis rat-characterization of the activity of peripheral myelin and
P2. Brain Res 1980;184:439-54.

30 Osterman PG, Lundemo G, Pirskanen R, et al. Beneficial effects of plasma exchange in acute inflammatory polyradiculoneuropathy. Lancet 1984;ii:1296-9. 